\title{
Determination of Irrigation Time Using Plant Water Stress Index Values of Second Crop Sunflower in Semi-Arid Climate Conditions
}

\begin{abstract}
Ali Beyhan Uçak ${ }^{1, a, *}$, Halis Seçme ${ }^{1, b}$
${ }^{1}$ Department of Biosystems Engineering, Faculty of Agriculture, Siirt University, 56100 Siirt, Turkey *Corresponding author

A R T I C L E I N F O A B S T R A C T

Research Article

This study was carried out in 2020 to determine crop water stress index (CWSI) by using infrared thermometer (IRT) data calculated by leaf canopy temperature measurements of the second crop sunflower genotype in semi-arid climate conditions, and to determine the relationships between irrigation time, seed yield of sunflower plant and CWSI by using these index values. Irrigation program consisted of a full irrigation and 2 different levels of stress, which were 100\% (I100), 70\% (I70), 35\% (I35) of water losses within the effective root depth of $90 \mathrm{~cm}$ every 7 days. A total of $644 \mathrm{~mm}$ of irrigation water was applied to I100 (control) irrigation. The water consumption for full irrigation was $721 \mathrm{~mm}$ and the yield was $3516.00 \mathrm{~kg} / \mathrm{ha}$. Lower limit (LL) value without water stress required to determine plant water stress index was Tc-Ta=-2.528 $\times \mathrm{VPD}+0.749\left(\mathrm{R}^{2}=0.814\right)$ and upper limit (UL) value, where the plant is completely under water stress, was determined as $+3.27^{\circ} \mathrm{C}$. Crop water stress index value threshold at which sunflower seed yield started to decrease was calculated as 0.33 using the infrared thermometer measurements at the time of irrigation. In addition, a negative correlation was obtained between sunflower seed yield and CWSI values. The

results revealed that the yield tends to decrease as the CWSI increases.

Keywords:

Sunflower

Crop water stress index

Irrigation time

Correlation
\end{abstract}

\section{Introduction}

Irregular and insufficient precipitation throughout a year is one of the most important external environmental stress factors that negatively affect agricultural production (Cattivelli et al., 2008). Water stress is defined as the insufficient precipitation for plant cultivation, or the amount of soil water or moisture in effective plant root depth $(0-90$ or $0-120 \mathrm{~cm})$ is less than the requirement of plants, and slows down or adversely affects plant growth (Uçak et al., 2016). Water stress and high temperature are the leading abiotic stress factors (Kozlowski and Pallardy, 1997). The first sign of water stress in plants occurs at the stomatal level, and stomata are closed to prevent further water loss by transpiration (Flexas and Medrano, 2002). Jackson (1982) explained how to measure leaf crown temperature (vegetation temperature) with an infrared thermometer, which is accepted as an indicator of the plant water stress index, and what should be considered in using infrared thermometer. The researchers stated that he temperature of plant leaf crown can be measured with a portable infrared thermometer, the device should be held at an angle of $30^{\circ}$ from the ground during measurement, and the accurate measurements can be carried out when vegetation cover is $80 \%$. Neither soil water content nor atmospheric humidity can determine internal water status of plants as accurately as the crop water stress index (CWSI) (Reginato and Howe, 1985). Therefore, methods aiming to determine the internal water status of plants are used by many researchers in preparing the irrigation programs (Reginato and Howe, 1985; Yazar, 1993). The slope and intersection of the lower boundary which is the threshold without water stress increase until vegetation cover reaches $70 \%$. The slope of lower boundary line without water stress and the correlation coefficient obtained from measurements when the crown temperature is greater than $27.4^{\circ} \mathrm{C}$ are higher than that obtained from daily measurements (Wanjura et al., 1990). Horst et al. (1989) stated that the lower limit without water stress depends on plant species and variety and environmental 
conditions, and is also affected by wind speed, net radiation and plant crown. Uçak et al. (2017a) revealed that CWSI values were different in 6 different sunflower lines. Uçak et al. (2017b) determined the CWSI values of 30 peanut lines. The lowest CWSI and the highest yield were recorded in Sultan line. Ekinci (2017) indicated that the yield of 17 second crop maize cultivars varied inversely with the CWSI values. Previous studies showed that CWSI can vary by plant variety and line, and drought-resistant lines or cultivars can be identified by the CWSI index. Gençoğlan (1996) prepared an irrigation program using the CWSI determined from infrared thermometer (IRT) and porometer observations in Çukurova conditions. The researcher reported that the grain yield started to decrease when the threshold CWSI value determined from infrared observations before irrigation was 0.19 , the threshold value determined from porometer observations was 0.26 , and there would be no yield loss in irrigated corn under these conditions. Fischer (2001) reported that the leaf crown temperature (cover temperature) of the plant is an important criterion determining the difference from the ambient air temperature, and the leaf crown temperature is lower than the air temperature. The researcher developed the plant water stress index by using the relationship between the crown temperature and the air temperature difference versus the vapor pressure gap of the air. Plants should be irrigated when reach a certain water stress index value. This threshold value varies from plant to plant, climate and cultivation techniques (Çolak et al., 2012). Gençel (2009) prepared an irrigation program using CWSI values. The researcher determined that the grain yield started to decrease when the threshold CWSI value determined from infrared observations before irrigation was between 0.35 and 0.40 (just before irrigation) in the most frequently irrigated I40 level and to zero approximately two days after irrigation. Tanriverdi (2010) reported that water stress index (WSI), or CWSI and water deficiency index (WDI) are useful tools that can be used to optimize irrigation time. The water stress in plants can be determined quantitatively using measurement and observation-based criteria. Aforementioned parameters are the difference in plant crown and air temperature and the vapor pressure gap of the air (Jackson et al., 1981).

Moroni et al. (2012) emphasized that the fastest and most accurate method for measuring water stress is the measurement of canopy (leaf-crown) temperature (CWSI). In general, the decrease in soil moisture before irrigation has an increasing effect on plant crown temperature values, and CWSI values increase with decreasing moisture in the soil (Kırnak and Gençoğlan, 2001). The CWSI value determined by using the lower (LL) and upper limit (UL) lines determined theoretically and experimentally varies between 0 and 1 (Gençoğlan and Yazar, 1999). Significant negative correlation was found between CWSI and maize yield in a study conducted to determine the resistance of sugar corn lines to water stress (Uçak et al., 2016). Çamoğlu et al. (2011) reported that leaf water content values can be used in the instant determination of plant water stress.

Some researchers have stated that the leaf crown temperature determined by infrared thermometer (IRT) measurements and the CWSI values calculated by using these measurements can be used in the preparation of irrigation plans (Clawson and Blad, 1982). On the other hand, Nielsen and Gardner (1987) reported that the irrigation time can be determined by using the CWSI values, but the amount of irrigation water to be applied cannot be determined with the aforementioned method. Studies have been carried out to determine the CWSI values for wheat, corn, chickpea and some cultivated plants, however, there are not enough studies carried out to determine the irrigation time of sunflower plants by using CWSI values and to examine the relationship between CWSI values and crop yields. Therefore, the aim of this study was to determine the CWSI value by using the leaf crown temperature values measured in the second crop sunflower plant grown under Siirt conditions in 2020, to determine the stress threshold value (sunflower irrigation time) where the decrease in yield begins, and to determine the relationship between grain yield and CWSI by correlation analysis.

\section{Material and Method}

Plant material of the study was P63LE113 hybrid sunflower genotype. The experiment was carried out according to the randomized blocks design with three replications. The interrow spacing was $70 \mathrm{~cm}$, each plot had 4 rows, and the dimension of each plot was $6 \mathrm{~m} \times 2.8$ $\mathrm{m}$. After the wheat harvest, the field was prepared for planting and seeds were planted on 16 June 2020. Before planting, di-ammonium phosphate and urea fertilizers were applied homogeneously at doses of $80 \mathrm{~kg} \mathrm{P} / \mathrm{ha}$ and $40 \mathrm{~kg}$ $\mathrm{N} / \mathrm{ha}$. In the harvest of sunflower plants, one row from the edges of each plot, $50 \mathrm{~cm}$ distance from the beginning and the end of each plot were not used to avoid from edge effect, and the seed yield of each plot was determined in the remaining two rows. Harvest was carried out on 29 October 2020. Hoeing and throat filling operations were carried out for weed control at 3 to 4 leaves stage. Plants were irrigated by drip irrigation method (on time and in sufficient amount) (Figure 1). The amount of irrigation water applied was adjusted to the field capacity moisture content. Seed yield and plant water stress index (CWSI) were calculated. The study was carried out under semi-arid climate conditions, in the experimental field of the Agricultural Faculty, Siirt University, during 2020 second crop sunflower growing season. The study consisted of one full and two deficit irrigation levels in a $90 \mathrm{~cm}$ soil profile. In full irrigation, $100 \%$ (I100, control) of water consumed was applied 7 days interval, and in deficit irrigation; $70 \%$ (I70) and 35\% (I35) of I100 were applied.

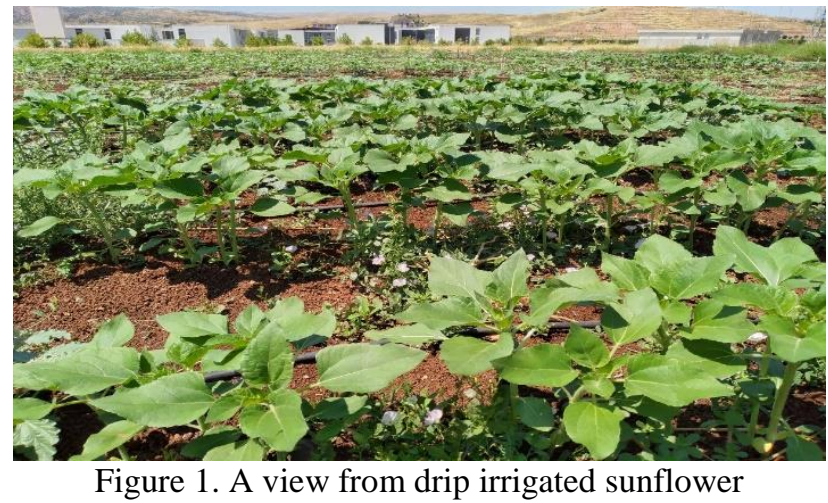


Plants were irrigated 8 times and the changes in soil water content were followed by gravimetric method. Eight irrigation events can be attributed to the high evapotranspiration in semi-arid climate conditions during July and August. Data on climate were given in Table 1. The study area is mostly under the influence of dry and hot tropical air masses settled in the Basra low pressure center during the summer season. The highest day time temperature rises above $40^{\circ} \mathrm{C}$. The region in winter is under the influence of fronts coming from the Central Mediterranean. The front activities cause precipitations which continue until April (Atalay and Mortan, 2013). Average temperatures in the summer period (June, July, August) and in the winter period (December, January, February) were not below $26^{\circ} \mathrm{C}$ and $2.7^{\circ} \mathrm{C}$, respectively. The long-term average highest relative humidity of the study area was measured in January with $70.2 \%$ and the lowest in August with 26.9\%. Annual average relative humidity is $50.41 \%$ and the long-term annual average precipitation is $669.2 \mathrm{~mm}$. Monthly precipitation in the region varies between $103.6 \mathrm{~mm}$ (April) and $1.3 \mathrm{~mm}$ (August) (Atalay and Mortan, 2013). Moisture content at field capacity $(33 \mathrm{kPa})$ and permanent wilting point $(1500$ $\mathrm{kPa}$ ) and bulk density were determined in undisturbed soil samples (Blake and Hartge 1986). Some physical and chemical properties of the soil in experimental field were given in Table 2. Electrical conductivity of the soil was low, the lime content was not high to pose a problem for plant growth, and soil has a clayey texture. The method specified by Tüzüner (1990) was used to determine the electrical conductivity, $\mathrm{pH}$ and anion and cation contents of irrigation water. Irrigation water quality was $\mathrm{C} 2 \mathrm{~S} 1$. The electrical conductivity of irrigation water was $0.34 \mathrm{dS} / \mathrm{m}$, and $\mathrm{pH}$ was 7.20. The irrigation water used in the experiment does not pose a problem for irrigation of sunflower plant.

Table 1. Climate data for long-term and study year (2020)

\begin{tabular}{c|llllllll}
\hline Year & Months & HAT $\left({ }^{\circ} \mathrm{C}\right)$ & MT $\left({ }^{\circ} \mathrm{C}\right)$ & LAT $\left({ }^{\circ} \mathrm{C}\right)$ & AH $(\%)$ & AWS $\left(\mathrm{m} \mathrm{s}^{-1}\right)$ & ASD $(\mathrm{h})$ & TP $(\mathrm{mm})$ \\
\hline \multirow{5}{*}{ Average } & May & 25.2 & 19.4 & 9.0 & 49.3 & 1.0 & 9.1 & 36.9 \\
$1965-2019$ & June & 27.2 & 26.0 & 17.8 & 34.9 & 1.1 & 11.6 & 11.5 \\
& Auly & 35.1 & 30.5 & 23.4 & 30.3 & 1.1 & 12.3 & 0.6 \\
& September & 34.5 & 30.3 & 27.0 & 29.5 & 1.0 & 11.4 & 2.7 \\
& October & 24.5 & 25.1 & 14.7 & 37.4 & 1.0 & 10.1 & 7.0 \\
\hline \multirow{5}{*}{2020} & May & 24.69 & 21.29 & 14.59 & 51.77 & 1.0 & 9.3 & 37.7 \\
& June & 28.19 & 28.41 & 20.25 & 34.40 & 1.1 & 12.0 & 9.3 \\
& July & 36.24 & 33.19 & 25.35 & 29.69 & 1.0 & 12.5 & 0.1 \\
& August & 35.92 & 32.45 & 24.73 & 29.95 & 1.0 & 11.5 & 0.0 \\
& September & 32.23 & 27.43 & 21.65 & 36.79 & 1.1 & 10.0 & 12.2 \\
& October & 21.1 & 19.7 & 12.0 & 44.2 & 1.0 & 7.3 & 69.20 \\
\hline
\end{tabular}

HAT: Highest Average Temperature, MT: Mean Temperature, LAT: Lowest average temperature, AH: Average humidity, AWS: Average wind speed, ASD: Average number of sunny days, TP: Total precipitation

Table 2. Some physical and chemical properties of soils in the experimental field

\begin{tabular}{|c|c|c|c|}
\hline \multirow{2}{*}{ Properties } & \multicolumn{3}{|c|}{ Soil layers $(\mathrm{cm})$} \\
\hline & $0-30$ & $30-60$ & $60-90$ \\
\hline Clay $(\%)$ & 62.00 & 58.00 & 55.00 \\
\hline Silt $(\%)$ & 20.00 & 25.00 & 32.00 \\
\hline Sand $(\%)$ & 18.00 & 17.00 & 13.00 \\
\hline Texture & Clay & Clay & Clay \\
\hline Field capacity $(\mathrm{Pw})$ & 33.52 & 36.04 & 35.38 \\
\hline Wilting point (Pwp) & 24.44 & 26.08 & 25.57 \\
\hline Bulk density $\left(\mathrm{g} \mathrm{cm}^{-3}\right)$ & 1.42 & 1.39 & 1.41 \\
\hline $\mathrm{pH}\left(1.25 \mathrm{sw}^{-1}\right)$ & 7.50 & 7.66 & 7.91 \\
\hline Electrical conductivity $\left(\mathrm{dS} \mathrm{m}^{-1}\right)$ & 1.55 & 1.77 & 1.75 \\
\hline Organic matter $(\%)$ & 3.09 & 2.06 & 1.80 \\
\hline $\mathrm{CaCO}_{3}(\%)$ & 6.40 & 1.90 & 1.90 \\
\hline
\end{tabular}

The moisture content in $90 \mathrm{~cm}$ of soil profile was determined by gravimetric method before each irrigation. The moisture content $(\%)$ determined for each layer was converted to moisture content in depth using the following equation.

$$
\mathrm{d}=\frac{\mathrm{Pw} \times \mathrm{As} \times \mathrm{D}}{10}
$$

In the equation, $\mathrm{d}$ is water content of soil moisture in depth (mm), Pw is moisture content determined for each layer $(\%)$, As is soil bulk density $\left(\mathrm{g} / \mathrm{cm}^{3}\right)$ and D is layer depth $(\mathrm{cm})$. The amount of total water $(\mathrm{dT})$ for $90 \mathrm{~cm}$ of soil profile was calculated by summing the water depth calculated for each layer.

$$
\mathrm{d}_{\mathrm{T}}=\mathrm{d}_{(0-30)}+\mathrm{d}_{(30-60)}+\mathrm{d}_{(60-90)}
$$

The volume of water for each plot was calculated using Equation 3 by multiplying the total amount of water with the plot area, the percentage of irrigation deficit $(1,0.70 .0 .35)$ and the percentage of surface cover.

$$
\mathrm{V}=\mathrm{d}_{\mathrm{T}}, \times \mathrm{A} \times \mathrm{U}_{\mathrm{o}} \mathrm{Xp}
$$


In equation; $\mathrm{V}$ is the volume of water to be given to plots $(\mathrm{L}), \mathrm{A}$ is plot area $\left(\mathrm{m}^{2}\right)$, Uo is percentage of deficit $(\%)$ and $\mathrm{P}$ is cover percentage $(\%)$. Coverage percentage was calculated by dividing the plant crown width by the plant row spacing. Percentage of plant cover was fixed at 0.30 until $30 \%$, true value was used until $80 \%$, and then fixed the value at $80 \%$. The lateral lines in the drip irrigation system had an outer diameter of $16 \mathrm{~mm}$, and the drippers were internally permeable and had a constant flow. One lateral was placed on each plant row. After calculating the amount of water given to the plots, the irrigation water applied was passed through a water meter.

Plant water stress index (CWSI) measurements were started with infrared thermometers, before and after irrigation, when plants covered approximately $80 \%$ of soil surface, and the measurements continued until physiological maturity. Crown temperature (Tc) measurements were carried out between 12:00 and 14:00 when the weather was completely clear or the clouds did not block the sun. The average crown temperature of a parcel was calculated by the average of 12 measurements in the direction of the diagonals of a plot (from 4 corners). At the beginning and end of the plant crown temperature measurements, wet and dry thermometer values were recorded with a digital psychrometer.

The empirical method introduced by Idso et al. (1981) was used to determine the plant water stress index (CWSI). The CWSI was calculated with the following equation (Idso et al., 1981).

$$
\text { CWSI }=\frac{\left[\left(T_{c}-T_{a}\right)-L L\right]}{U L-L L}
$$

In equation; Tc is the crown temperature $\left({ }^{\circ} \mathrm{C}\right)$, Ta is the air temperature $\left({ }^{\circ} \mathrm{C}\right), \mathrm{LL}$ is the lower limit where the plants are not under water stress, and UL is the upper limit where the plants are completely stressed.

The lower limit (LL) was calculated by the following equation obtained by regression analysis between the crown-air temperature difference and the vapor pressure gap (VPD, kPa) defined by Idso (1982).

$$
\mathrm{T}_{\mathrm{c}}-\mathrm{T}_{\mathrm{a}}=\mathrm{a}-\mathrm{b} \times \mathrm{VPD}
$$

In equation; $\mathrm{a}$ is the cross-sectional value of the line $\left({ }^{\circ} \mathrm{C}\right)$ and $\mathrm{b}$ is the slope of the line $\left({ }^{\circ} \mathrm{C} \mathrm{kPa}-1\right)$.

The vapor pressure gap was calculated using the basic psychrometry equations of Howell et al. (1992). These equations were given below.

$$
\mathrm{e}_{\mathrm{w}}=0.61078 \exp \left[\frac{17.27 \mathrm{~T}_{\mathrm{w}}}{237.3+\mathrm{T}_{\mathrm{w}}}\right]
$$

In equations; saturated vapor pressure $(\mathrm{kPa})$ at wet bulb temperature ew; actual vapor pressure at air temperature $(\mathrm{kPa}), \mathrm{Tw}$, wet thermometer temperature $\left({ }^{\circ} \mathrm{C}\right)$

$$
e_{a}=e_{w}-\left[(A P)\left(T_{a}-T_{w}\right)\right]
$$

In equations; $\mathrm{e}_{\mathrm{a}}$ and $\mathrm{e}_{\mathrm{w}}$ actual vapor pressure at air temperature $(\mathrm{kPa}), \mathrm{A}$ is the psychrometric constant $\left(\mathrm{kPa}^{\circ} \mathrm{C}-1\right) ; \mathrm{P}$ is the barometric pressure, $(\mathrm{kPa})$; Ta is the air temperature $\left({ }^{\circ} \mathrm{C}\right)$; Tw, wet thermometer temperature $\left({ }^{\circ} \mathrm{C}\right)$
The psychometric constant (A) was calculated using the following equation.

$$
\mathrm{A}=\left[0.00055\left(1+0.00115 \mathrm{~T}_{\mathrm{w}}\right)\right]
$$

In equations $\mathrm{A}$; The psychometric constant was calculated using the following equation. Tw, wet thermometer temperature $\left({ }^{\circ} \mathrm{C}\right.$

The saturated vapor pressure was determined using the following equation.

$$
\mathrm{e}_{\mathrm{a}} \times\left(\mathrm{T}_{\mathrm{a}}\right)=0.61078 \exp \left[\frac{17.27 \mathrm{~T}_{\mathrm{a}}}{237.3+\mathrm{T}_{\mathrm{a}}}\right]
$$

In equations ea, actual vapor pressure at air temperature $(\mathrm{kPa}), \mathrm{Ta}$ is the air temperature $\left({ }^{\circ} \mathrm{C}\right)$;

The vapor pressure gap (VPD) was calculated from the saturated vapor pressure at the dry thermometer temperature and the actual vapor pressure difference at the same temperature.

$$
\mathrm{VPD}=\left[\left(\mathrm{e}_{\mathrm{a}} \times\left(\mathrm{T}_{\mathrm{a}}\right)-\mathrm{e}_{\mathrm{a}}\right)\right]
$$

In equation VPD the vapor pressure gap $e_{a} \times\left(T_{a}\right)$; is the saturated vapor pressure $(\mathrm{kPa})$ calculated at dry thermometer temperature; ea, actual vapor pressure at air temperature $(\mathrm{kPa})$,

$$
\begin{gathered}
\mathrm{T}_{\mathrm{c}}-\mathrm{T}_{\mathrm{a}}=\mathrm{a}-\mathrm{b} \mathrm{VPG} \\
\mathrm{VPG}=\left[\left(\mathrm{e}_{\mathrm{a}} \times\left(\mathrm{T}_{\mathrm{a}}\right)-\mathrm{e}_{\mathrm{a}} \times\left(\mathrm{T}_{\mathrm{a}}+\mathrm{a}\right)\right)\right]
\end{gathered}
$$

In equation VPG is the negative atmospheric vapor pressure slope required for zero crown-air vapor pressure training; $e_{a} \times\left(T_{a}\right)$; is the saturated vapor pressure $(\mathrm{kPa})$ calculated at dry thermometer temperature; ea, actual vapor pressure at air temperature $(\mathrm{kPa})$; Ta is the air temperature $\left({ }^{\circ} \mathrm{C}\right)$; a are the regression coefficients in the lower limit (LL) equation without water stress;

Where: $a$ and $b$ are the regression coefficients in the lower limit (LL) equation without water stress; VPG is the negative atmospheric vapor pressure slope required for zero crown-air vapor pressure training.

Data were subjected to variance analysis and statistically significant treatments were compared with the LSD test. Correlation analysis was performed to determine the relationship between the traits. Thus, the significance level and positive or negative aspects of the relationships were determined (Der and Everitt, 2002).

\section{Results and Discussion}

The amount of irrigation water depending on the irrigation treatments ranged from approximately 60.4 to $153 \mathrm{~mm}$ (Table 3). Total amount of irrigation water given to the I35 and I100 treatments were $225.00 \mathrm{~mm}$ and 644.00 $\mathrm{mm}$, respectively. Total irrigation water in the $\mathrm{I70}$ treatments varied between these two values. Seasonal water consumption (ETa) of the sunflower genotype within effective root depth of $90 \mathrm{~cm}$ was $684 \mathrm{~mm}$ in $\mathrm{I100}$ irrigation, where water stress was at a minimum level, and $265 \mathrm{~mm}$ in I35 irrigation, where water stress was excessive. 
Lower and upper limits were calculated to determine the CWSI of the sunflower genotype. Lower limit (LL) equations to define potential transpiration status of the genotype and the upper limit (UL) equations to define status of plant under extreme water stress were given in Figure 2.

The lower limit (LL) equation, where there is no water stress in the plant, or plant potentially evapotranspirates, was determined as $\mathrm{Tc}-\mathrm{Ta}=-2.528 \times \mathrm{VPD}+0.749\left(\mathrm{R}^{2}=\right.$ 0.814) (Figure 2). In the equation, the intersection values of the LL line were positive. Idso (1982) reported that the intersection value cannot be less than zero. They also reported that this value is caused by the formation of a positive water vapor flow from the leaves to the atmosphere, even if the VPD is reduced to zero by saturating the atmosphere. The LL equation indicated that a positive water vapor flux towards the atmosphere occurs during the whole growing season in which measurements and observations are carried out (Köksal, 1995; Gençel, 2009). The upper limit (UL) equation, assumed to be completely under water stress, was determined as Tc - Ta $=1.169+0.0538$ VPG. The differences between the crown temperature and the air temperature in UL were determined as $1.169-0.572^{\circ} \mathrm{C}$, ignoring the slope due to the minimum slope in the UL equation. The CWSI values measured at different irrigation levels were predominantly ranged between 0 (no water stress) and 1 (maximum stress state), however, some of these values were negative. Negative CWSI values were caused due to the measurement values located at the lower part of the LL line (Figure 2). Average CWSI values determined for irrigation treatments were given in Table 3 . The average CWSI values determined for the irrigation treatments were 0.67 for I35 and 0.25 for I100. The CWSI values determined for the days of measurements during the growing season were given in Figure 3.

Table 3. Crop water stress index, irrigation water and crop water consumption values

\begin{tabular}{l|ccccc}
\hline $\begin{array}{c}\text { Irrigation } \\
\text { treatments }\end{array}$ & $\begin{array}{c}\text { Yield } \\
\left(\mathrm{kg} \mathrm{ha}^{-1}\right.\end{array}$ & $\begin{array}{c}\text { Crop water } \\
\text { stress index }\end{array}$ & $\begin{array}{c}\text { Irrigation water } \\
(\mathrm{mm})\end{array}$ & $\begin{array}{c}\text { Crop water consumption } \\
(\mathrm{mm})\end{array}$ & $\begin{array}{c}\text { Water Use Efficiency } \\
\left(\mathrm{kg} \mathrm{da}^{-1} \mathrm{~mm}^{\mathrm{a}}\right)\end{array}$ \\
\hline I100 & $3516.00^{\mathrm{a}}$ & $0.25^{\mathrm{c}}$ & 644.00 & 684.00 & $0.51^{\mathrm{c}}$ \\
I70 & $2754.00^{\mathrm{b}}$ & $0.45^{\mathrm{b}}$ & 450.00 & 490.00 & $0.56^{\mathrm{b}}$ \\
I35 & $2387.00^{\mathrm{c}}$ & $0.67^{\mathrm{a}}$ & 225.00 & 265.00 & $0.90^{\mathrm{a}}$ \\
LSD & 181.82 & 0.015 & & & \\
\hline
\end{tabular}

*: $\mathrm{P}<0.05$ and $* * ; \mathrm{P}<0.01$. ns; not significant

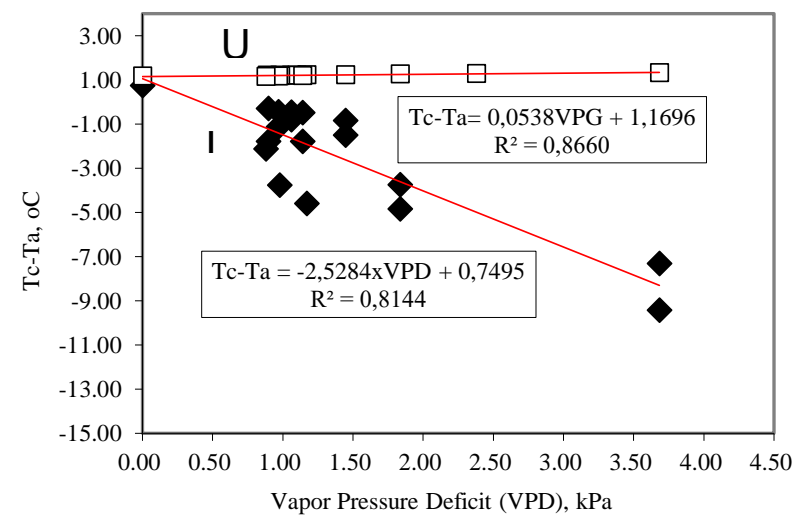

Figure 2. The lower and upper limit relationship values of the sunflower plant

The CWSI values, which increased depending on the severity (excess) and duration of the water stress applied, showed a tendency to be maximum before irrigation and to decrease after irrigation. Köksal (1995) reported that the CWSI values ranged between 0.13 and 0.43 for the highest water application, and between 0.42 and 073 for the the least water application in Çukurova conditions. The average CWSI values, calculated from IRT measurements carried out during the entire growing season of maize, were 0.391 and 0.393 for I0 irrigation level in the first and second years of the experiment, respectively; They also reported that the average CWSI value for I0 irrigation level was between 0.391 and 0.393 ; for I100 irrigation level was between 0.092 and 0.145 , and the average CWSI for other irrigation levels varied between these values. The decrease in the available water level at the plant root zone during

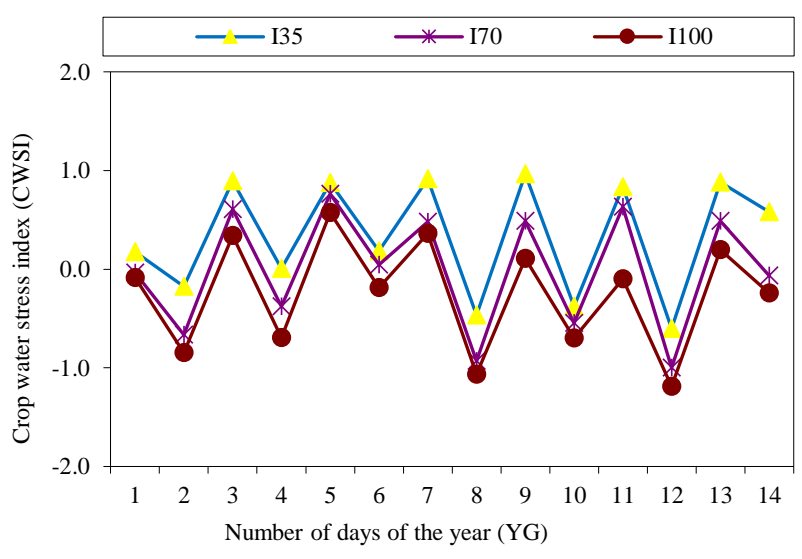

Figure 3. Crop water stress index values determined in irrigation treatments

irrigations caused a decrease in the CWSI values. Certain period of time is needed for the CWSI value to decrease after irrigation and this period varies between 4 and 5 days (Ödemiş and Baştuğ 1999). The researchers emphasized that the plant suffers from water stress as the amount of water in soil decreases, therefore the CWSI value increases. Gençoğlan and Yazar (1999) and Uçak et al. (2013) stated that the increase in water stress increased the CWSI value of maize. Erdem et al. (2006) indicated that different irrigation levels cause variation in the CWSI values and they measured the highest CWSI value in the least water applied treatment.

Kıraç (2016) compared conventional irrigation, alternate partial root dryness every 5 days (APRD5) and alternate partial root dryness every 10 days (APRD10) in Red Chief dwarf apples. The CWSI values ranged from 
0.10 to 0.52 for conventional irrigation, 0.12 to 0.64 for APRD5, and 0.18 to 0.64 for APRD10.

Şimşek et al. (2005) stated that the CWSI value varies depending on the amount of water applied and high CWSI values cause yield loss in plants. Gençel (2009) reported that the CWSI value was between 0.35 and 0.40 for the most frequently irrigated I40 treatment, between 0 and 0.55 for I60 treatment, which is similar to the irrigation program applied by the producers, and 1.0 for I80 treatment, which represents extremely stressed conditions in plants. The CWSI values varied between irrigation subjects depending on the amount of water at stress. The IRT observations have shown that the CWSI threshold at which yield starts to decrease was approximately 0.33. Köksal (1995) reported that the threshold value for the second crop corn plant grain yield was 0.33 and 0.32 for dry matter. Gençoğlan and Yazar (1999) reported the CWSI threshold value determined from infrared observations was 0.19 and the threshold value determined from porometer observations was 0.26 in Çukurova conditions. Reginato (1983) stated that plants do not suffer water stress where the CWSI value is less than or equal to 0.2 . The CWSI threshold values obtained in this study are similar to those reported by Gençoğlan and Yazar (1999), however, they are partially different from the CWSI threshold values of
Köksal (1995). The results can be associated with the different responses of genotypes obtained through breeding to moisture loss in soils. The results show that the CWSI at which the yield starts to decrease may vary depending on irrigation program, soil type, climatic conditions, type of cultivar, and status of cultivation as the first or secondary crop.

\section{Correlation Test}

The correlation coefficients ( $r$ ) between the CWSI of the sunflower plant and the yield, water use efficiency and chlorophyll content were given in Table 4 . The correlation coefficients indicated statistically significant relationships $(\mathrm{P} \leq 0.01)$ between all these properties. A significant negative correlation $(\mathrm{r}=-0.87)$ was recorded between CWSI and yield. In contrast, there was a significant positive $(r=0.77)$ relationship between CWSI and water use efficiency. Statistically significant negative $(r=-0.94)$ relationship was found between CWSI and chlorophyll content. Significant relationships between the traits investigated reveals that the increase in CWSI causes a decrease in yield, an increase in water use efficiency, and a decrease in chlorophyll content.

Table 4. Relationships between crop water stress index and other parameters

\begin{tabular}{l|cccc}
\hline & Yield & WUE & CWSI & CC \\
\hline Yield & 1.00 & $-0.49^{*}$ & $-0.87^{* *}$ & $0.88^{* *}$ \\
WUE & $-0.49^{*}$ & 1.00 & $0.77^{* *}$ & $-0.67^{* *}$ \\
CWSI & $-0.87^{* *}$ & $0.77^{* *}$ & 1.00 & $-0.94^{* *}$ \\
CC & $0.88^{* *}$ & $-0.67^{* *}$ & $-0.94^{* *}$ & 1.00 \\
\hline *: P<0.05 and **; P<0.01.ns; not significant, WUE; water use efficiency. CWSI; crop water stress index CC; chlorophyll content
\end{tabular}

*: $\mathrm{P}<0.05$ and **; $\mathrm{P}<0.01$. ns; not significant, WUE; water use efficiency. CWSI; crop water stress index. CC; chlorophyll content

\section{Conclusion and Recommendations}

This study was carried out as a field experiment in semi-arid climate conditions to determine crop water stress index of a sunflower genotype grown under water-free and water-stressed conditions and to determine the threshold value at which sunflower yield significantly decreases.

The crop water stress threshold value of the second crop sunflower plant grown in semi-arid climatic conditions is 0.33 , which indicates time for irrigation. No statistically significant yield loss will occur when irrigation is carried out at a crop water stress threshold value of 0.33 . In addition, $30 \%$ water reduction can be applied in regions where irrigation water is limited. Yield may significantly decrease if the CWSI is higher than the threshold value. The data obtained indicated that yield can be estimated by using the linear functional relationships between sunflower seed yield and CWSI obtained by using the leaf crown temperature measurements carried out at irrigation time. Stress screening parameters used in the study can be used to determine the resistance of different genotypes to water stress. The findings obtained in this study can also be tested in future field studies. On the other hand, conducting similar studies in the study area would also be very beneficial.

\section{References}

Atalay İ, Mortan K. 2013. Regional Geography of Turkey (5th ed.). İnk1lâp Bookstore, Istanbul.

Blake GR, Hartge KH. 1986. Bulk density. In: Klute, A., Ed., Methods of Soil Analysis, Part 1-Physical and Mineralogical Methods, 2nd Edition, Agronomy Monograph 9, American Society of Agronomy-Soil Science Society of America, Madison, 363-382. DOI: https://doi.org/10.2136/sssabookser5.1.2ed.c14

Cattivelli L, Rizza F, Badeck FW, Mazzucotelli E, Mastrangelo AM, Francia E, Mare C, Tondelli A, Stanca AM. 2008. Drought tolerance improvement in crop plants: an integrated view from breeding to genomics. Field Crops Research, 105: 1-14. DOI: https://doi.org/10.1016/j.fcr.2007.07.004

Clawson KL, Blad BL. 1982. Infrared Thermometry for Scheduling Irrigation of Corn. Agron. J. 74: 311-316 DOI: https://doi.org/10.2134/agronj1982.00021962007400020013x

Çamoglu G, Genç, L, Aşık Ş. 2011. The Effects of Water Stress on Physiological and Morphological Parameters of Sweet Corn (Zeamays saccharata Sturt.). Ege University Faculty of Agriculture Journal, Aydın, Turkey, 48 (2): 141-149. ISSN 1018-8851.

Çolak YB, Yazar A, Sezen SM, Tangolar S, Gökçel F, Eker S. 2012. Monitoring Plant Water Stress with Infrared Thermometer in Alphonse Lavallee Table Grape Varieties in the Mediterranean Region, II. National Irrigation and Agricultural Structures Symposium, İzmir, Turkey, 24-25 May, 1:101-108 
Der G, Everitt BS. 2002. A Handbook Of Statistical Analyses Using SAS. Second Edition. CRC Press LLC. 2000 N.W. Corporate Blvd. Boca Raton. Florida 3431. USA. ISBN 13978-1-58488-785-0 (eBook)

Ekinci M. 2017. Investigation of Agromorphological Characteristics, Water Stress and Stoma Indices of Second Crop Corn Varieties in Kahramanmaraş Conditions. Kahramanmaraş Sütçü İmam University, Graduate School of Natural and Applied Sciences, Department of Field Crops. Kahramanmaras. (In Turkish).

Erdem T, Erdem Y, Orta AH, Okursoy H. 2006. Use of a Crop Water Stress Index for Scheduling the Irrigation of Sunflower (Helianthus annuus L.). Turk J Agric For 30(1): 11-20.

Fischer RA. 2001. Selection Traits for Improving Yield Potential. Application of Physiology in Wheat Breeding, Chapt-13, P.148-159.

Flexas J, Medrano H. 2002. Drought-inhibition of photosynthesis in C3 plants: stomatal and non-stomatal limitations revisited. Ann. Bot. 83. 183-189

For $\mathrm{PhD} /$ Agricultural Structures and Irrigation

Gençel B. 2009. Estimation of Irrigation Water Amount by Using the Crop Water Stress Index (CWSI) in the Second Crop Corn Plant. Science Ins. Department of Agricultural Structures and Irrigation, Cukurova University, Adana, Turkey.

For $\mathrm{PhD} /$ Agricultural Structures and Irrigation

Gençoğlan C. 1996. Water Yield Relationships of Corn Plant, Determination of Root Distribution and Plant Water Stress Index and Investigation of the Compatibility of the CERES Maize Plant Growth Model to the Region. C.U. Science Ins. Department of Agricultural Structures and Irrigation, Cukurova University, Adana, Turkey.

Gençoğlan C, Yazar A. 1999. Determination of Crop Water Stress Index (CWSI) and Irrigation Time Using Infrared Thermometer Values in the First Crop Corn Plant Grown in Çukurova Conditions. Tr. J. of Agriculture and Forestry. 23:87-95.

Horst GL, O’Toole JC, Faver KL. 1989. Seasonal and Species Variation in Baseline Functions for Determining Crop Water Stress Indices in Turfgrass. Crop Sci 29: 1227-1232.

Howell TA, Yazar A, Schneider AD, Dusek DA, Copeland KS. 1992. Lepa Irrigation of Corn and Sorghum. Center Pivot Field at USDA-ARS. Conservation and Production Research Laboratory, Bushland, Tx.

Idso SB, Jackson RD, Pinter PJ, Reginato RJ, Hatfield JL. 1981. Normalizing The Stress-Degree-Day Parameter for Environmental Variability. Agricultural Meteorology, 24:4555.

Idso SB. 1982. Non-Water-Stressed Baselines: A Key to Measuring and Interpreting Plant Water Stress. Agric. Meteorology. 27: 59-70.

Jackson RD, Idso SB, Reginato RJ, Pinter PJ. 1981. Canopy Temperature as a Crop Water Stress Indicator. Water Resources Research, Vol. 17, No. 4 Page 1133-1138.

Jackson RD. 1982. Canopy Temperature and Crop Water Stress. Advances in Irrigation. Edited by Daniel Hillel. Academic Press 1: 43-85. New York. London.

For $\mathrm{PhD} /$ Biosystems Engineering Department

Kıraç AM. 2016. Determining the Response of MM 106 Rootstock "Red Chief" Apple Varieties to Irrigation Techniques with Restricted and Partial Root Dryness. Institute of Science and Technology, Kahramanmaraş Sütçü İmam University, Kahramanmaraș, Turkey.
Kirnak H, Gencoglan C. 2001. Use of crop water stress index for scheduling irrigation in second crop corn. Harran Univ. Journal of Agricultural Faculty, 5(3-4): 67-75.

Kozlowski TT, Pallardy SG. 1997. Physiology of Woody Plants. Academic Press. San Diego. ISBN 13:978-0-120424162-6.

For PhD/Agricultural Structures and Irrigation

Köksal H. 1995. A Research on Second Crop Corn Plant Water Production Functions in Çukurova Conditions and Determining the Suitability of Different Growth Models to the Region, Department of Agricultural Structures and Irrigation, Cukurova University, Adana, Turkey.

Moroni IF, Fraysse M, Presotto A, Cantamutto M. 2012. Evaluation of Argentine wild sunflower biotypes for drought stress during reproductive stage. Proc. 18th International Sunflower Conference. Mar del Plata. Argentina. 420-425.

Nielsen DC, Gardner BR. 1987. Scheduling Irrigations for Corn with the Crop Water Stress Index (CWSI). Applied Agricultural Research Vol. 2, No. 5, pp. 295-300.

Ödemiş R, Baştuğ R. 1999. Evaluation of Crop Water Stress and Irrigation Programming in Cotton Using Infrared Thermometer Technique. Turkish Journal of Agriculture and Forestry, 23:31-37.

Reginato RJ. 1983. Field Qualification of Crop Water Stress. Trans. Amer. Soc. of Agr. Eng. 26(3): $772-781$.

Reginato RJ, Howe J. 1985. Irrigation Scheduling Using Crop Indicators. Journal of Irrigation and Drainage Engineering Asce. Vol. 111. No. 2. p: 125-133.

Şimsek M, Tonkaz T, Kaçıra M, Çömlekçioglu N, Dogan Z. 2005. The Effects of Different Irrigation Regimes on Cucumber (Cucumbis sativus L.) Yield and Yield Characteristics Under Open Field Conditions. Agricultural Water Management, 73:173-191.

Tanrıverdi Ç. 2010. Improved Agricultural Management with Remote Sensing in Determining Water Stress Indices. Journal of Applied Remote Sensing, 1-1.

Tüzüner A. 1990. Soil and Water Analysis Laboratory Handbook. T.R. Ministry of Agriculture, Forestry and Rural Affairs. General Directorate of Rural Services. Ankara, Turkey.

Uçak AB, Gençoğlan C, Değirmenci H. 2013. The effect of direct and traditional seeding methods and different water levels on the water-yield relationship of drip irrigated corn. J Food Agric Environ 11(3\&4): 828-833.

Uçak AB, Oktem A, Sezer C, Cengiz R, Inal B. 2016. Determination of Arid and Temperature Resistant Sweet Corn (Zea mays saccharata Sturt) Lines. International Journal of Environmental \& Agriculture Research (IJOEAR) 2:7, 7988, ISSN: 2454-1850.

Uçak AB, Gençoğlan C, Çil A, İnal B. 2017a. Identification of Drought Resistant Sun flower genotypes (Helianthus annuus L.). Fresenius Environmental Bulletin 26(11): 6780-6790, ISSN 1018-4619.

Uçak AB, Çil A, Tüysüz DM, Şahin H, Ekin Ş. 2017b. Determination of Water Stress Tolerant Peanut (Arachis hypogaea L.) Lines. KSU Journal of Natural Sciences 20: 246-251, DOI: 10.18016/ksudobil.349225.

Wanjura DF, Hatfield JL, Upchurch DR. 1990. Crop Water Stress Index Relationships with Crop Productivity. Irrig. Sci., 11:93-99.

Yazar A. 1993. Plant Water Stress Measurement with an Infrared Thermometer. S. Sener Editor, New Developments in Irrigation Technology. General Directorate of Soil and Water Resources Research. Publication No: 76. Tarsus. 